\title{
COMMUNICATION STRATEGIES OF POLISH EXILES OF THE SECOND HALF OF THE 19TH CENTURY (THE EXAMPLE OF TARA AND KURGAN)
}

\author{
Svetlana A. Mulina
}

Dostoevsky Omsk State University. Omsk, Russia. Email: swetmulina[at]rambler.ru

\begin{abstract}
Diaspora studies penetrating into the Polish-Siberian theme since the late 1990s focused as a rule on the study of stable institutions, social organizations created by migrants for the preservation and development of ethnic community, and articulation of ethnic interests. However, such organizations among the Siberian Poles appeared only in the late XIX-early XX centuries. To understand the ethnic processes that took place among Polish migrants in the earlier period, the study of informal social ties of Polish migrants, various elements of group solidarity and communication systems becomes of paramount importance.
\end{abstract}

The purpose of this study is to reconstruct, on the basis of office documentation and correspondence, the communication strategies of exiled participants in the revolts of the 1863-1864 on the example of two cities of Tobolsk province, namely, Kurgan and Tara.

As a result of the study, we recorded the existence of a fraternity in Tara, covering most of the Poles who lived in the city. The self-organization of the exiles was facilitated by the presence of ready-made social structures - large traditional families and the system of communication between them that has developed at home. The emersion of the community in Kurgan was the result of the efforts of a group of exiled nobles who had a good education. In the conditions of a limited social status, and the absence of rich compatriots, the social value of this community turned out to be insufficient to become the center of attraction for Poles.

\section{Keywords}

Migration; Communication; Community; Polish Exile; Adaptation; Family; Fellowship; Siberia; Tara; Kurgan 


\title{
СТРАТЕГИИ КОММУНИКАЦИИ ПОЛЬСКИХ ССЫЛЬНЫХ ВТОРОЙ ПОЛОВИНЫ ХІХ ВЕКА (НА ПРИМЕРЕ ТАРЫ И КУРГАНА)
}

\section{Мулина Светлана Анатольевна}

Омский государственный университет им. Ф. М. Достоевского. Омск, Россия. Email: swetmulina[at]rambler.ru

\begin{abstract}
Аннотация
Диаспоральные исследования, проникающие в польско-сибирскую тематику с конца 1990-х гг., как правило, концентрировали внимание на изучении устойчивых институтов, социальных организаций, создаваемых мигрантами для сохранения и развития этнической общности, артикуляции этнических интересов. Однако подобные организации в среде сибирских поляков появляются лишь в конце XIX - начале XX вв. А для понимания этнических процессов, имевших место у польских мигрантов в более ранний период, первостепенное значение приобретает изучение неформальных социальных связей польских мигрантов, различных элементов групповой солидарности и систем коммуникаций.
\end{abstract}

Цель данного исследования реконструировать на основе делопроизводственной документации и корреспонденции стратегии коммуникации ссыльных участников восстания 1863-1864 гг. на примере двух городов Тобольской губернии: Кургана и Тары.

В результате исследования мы зафиксировали существование в Таре землячества, охватывающего большую часть поляков, проживавших в городе. Самоорганизация ссыльных была облегчена наличием готовых социальных структур - больших традиционных семей и системой коммуникаций между ними, сложившейся на родине. В Кургане появление сообщества стало итогом усилий группы ссыльных дворян, имевших хорошее образование. В условиях ограниченного социального статуса, отсутствия богатых соотечественников, социальный капитал этого сообщества оказался недостаточным для того, чтобы стать центром притяжения поляков.

\section{Ключевые слова}

миграции; коммуникация; сообщество; польская ссылка; адаптация; семья; землячество; Сибирь; Тара; Курган

Это произведение доступно по лицензии Creative Commons «Attribution» («Атрибуция») 4.0 Всемирная 


\section{ВВЕДЕНИЕ}

Диаспоральные исследования, проникающие в польско-сибирскую тематику с конца 1990-х гг. как правило, концентрировали внимание на изучении устойчивых институтов, социальных организаций, создаваемых мигрантами для сохранения и развития этнической общности, самобытности, артикуляции этнических интересов (Нам, 2010, сс. 315-356; Островский, 2019, сс. 164-175). Однако подобные организации в среде сибирских поляков появляются лишь в конце XIX - начале XX вв. А для понимания этнических процессов, имевших место у польских мигрантов в более ранний период, в том числе во времена ссылки участников восстания 1863-1864 гг., первостепенную важность приобретает изучение неформальных социальных связей польских мигрантов, различных элементов групповой солидарности и систем коммуникаций.

Традиция рассматривать ссыльного как часть сообщества изгнанников появляется еще в XIX в. Польский исследователь Зигмунд Либрович отмечал, что общим для всех поляков в Сибири было то, что те, кто добивался удачи или смог обеспечить себе более-менее сносное существование, охотно делились с беднейшими соотечественниками. Солидарность, товарищеская жизнь, потребность поддерживать национальность и религию обнаруживаются среди поляков на каждом шагу (Librowicz, 1993, p. 215). На основе мемуарной литературы польские исследователи проанализировали феномен «польского дома», являвшегося в Сибири очагом польской культуры, центром притяжения для соотечественников. «Настоящим польским домом» был дом, где хозяйкой была полька - жена ссыльного. Женщины приносили в край изгнания тепло домашнего очага, место холостяцких вечеров занимали семейные встречи с гомоном детских голосов, атмосферой, напоминающей отчизну (Śliwowska, 1996, p. 186; Śliwowska \& Trynkowski, 2005, p. 148). Своего рода социальным центром помощи и информации стал дом Адольфа и Антонины Рошковских в Иркутске в 1844-1857 гг. (Nowiński, 2020). «Польским домом» исследователи называют также совместное хозяйство, которое вели несколько мужчин разного социального статуса, оказавшиеся в Сибири без семьи. Так дом Антония Бопре, созданный в 1840-1850-е гг. во многом благодаря финансовой поддержке его сестры Ксаверии, стал

«столицей польских ссыльных Забайкальского края, местом, в котором концентрировалась их организационная, культурная, научная и товарищеская жизнь. Этот дом позволил многим ссыльным пережить период ссылки с достоинством, а некоторым даже с выгодой» (Trynkowski, 2017, p. 77). 
И, наконец, существовали польские дома, в которых проживали ссыльные, не связанные совместным хозяйством. Например, поляки, сосланные за заговорщическую деятельность в солдаты, получив разрешение проживать на частных квартирах, часто селились группами и старались возродить атмосферу польской семьи (Caban, 2011, p. 377). Все три вида «семейных домов» позволяли ссыльным сохранять «польскость» (Цабан, 2021, с. 90).

Ярким примером солидарности ссыльных являлись организации взаимопомощи, так называемые огулы (ogóły). Наиболее организованными стали забайкальский и иркутский огулы, существовавшие в первой половине XIX в. Затем традиция огулов возродилась во время ссылки участников восстания 1863-1864 гг. (Caban \& Mulina, 2019, pp. 203-218) и продолжалась до конца существования Российской империи (Śliwowska \& Trynkowski, 2005, p. 177). Советская историография видела в этих организациях конспиративную сеть. Товарищество взаимного пособия в Кургане и подобные общества в других городах рассматривались как филиалы единой тайной организации, имевшей цель «возбуждения местного населения края к действиям против правительства и к восстанию общими силами вместе с поляками для низвержения существующего порядка» (Коваль, 1865, с. 124). Подобный подход не поддержали польские историки, полагавшие, что целью этих организаций являлось улучшение условий существования ссыльных в психологическом, социальном и материальном плане (Skok, 1974, p. 210). Составление моральных кодексов, организация касс взаимопомощи, артелей, самообразование, просветительская деятельность - все это позволяло сопротивляться растлевающей действительности и снискало уважение и благодарность местного населения (Jędrychowska, 2000). Интересной стала попытка рассмотреть деятельность польских обществ вспомоществования как диаспорных общин, моделировавших коллективные поведенческие стратегии ссыльных. Но такие организации оказались недолговечны. Контроль правительства и неоднородность польских колоний не позволили сложиться диаспорной общине, а тактика сегрегации противоречила объективным потребностям жизни и не находила отклика у соотечественников (Мулина, 2012, с. 146).

Менее исследованным сообществом применительно к польской ссылке XIX в. является землячество. «Неформальные, неприметные мини-сообщества», играющие «огромную роль в деле сохранения национальной и культурной самобытности пришельцев», историки фиксируют, реконструируя контакты между ссыльными: браки, кумовство, отдельные факты взаимопомощи. При этом даже в рамках 
одной статьи землячеством могут называть самые разные явления: в одних случаях приравнивая землячество к организации взаимопомощи, а в других распространяя его на всю колонию ссыльных в каком-либо населенном пункте (Оплаканская, 2004). Подобное происходит и с понятием община, которое часто применяют для характеристики всего польского населения, локализованного на определенной территории, видя в нем сплоченную этническую общность (Жарова, 2014).

Настоящее исследование предполагает взгляд на польские сообщества как системы коммуникаций. Адаптируя наработки социологов в изучении современных миграций, мы выделим следующие признаки наличия сообщества (Варшавер \& Рочева, 2014):

- совместное делание - члены сообщества чаще и охотнее поддерживают деятельность друг друга;

- использование социального капитала сообщества - индивиды используют социальные связи для привлечения ресурсов, которые отсутствуют у них самих;

- нормализация - члены сообществ совместно переживают сложный опыт и преобразуют его в приемлемый;

- создание общих смыслов - сообщество является зоной более интенсивного общения, в рамках которого выкристаллизовываются общие представления о мире.

Таким образом, коммуникационные стратегии будут рассматриваться в качестве неформальных социальных практик, выступающих в роли компенсаторного механизма по отношению к ограниченным ресурсам адаптации. Контакты с представителями своей мигрантской группы позволяют преодолеть экономические, социальные и психологические проблемы в процессе инкорпорации в принимающее общество.

Цель исследования: реконструировать стратегии коммуникации польских ссыльных на примере двух окружных городов Тобольской губернии: Кургана и Тары. Ограничение территориальных рамок вызвано необходимостью реконструкции персонального состава ссылки для выявления сообщества и его структуры. Выбор обусловлен тем, что в обоих городах была значительная польская колония, и оба населенных пункта пострадали от пожаров, прокатившихся в Сибири летом 1864 г. и обостривших отношение к ссыльным со стороны местного населения. Тобольский губернатор подчеркивал: 
«Особенно напряженное состояние в отношениях местных жителей к политическим ссыльным обнаружилось в Кургане и Таре, вследствие бывших там пожаров. Местная полиция, вообще не достаточная, не была в состоянии предотвратить столкновение и оградить невинных людей от незаслуженных оскорблений» (Вех, Крих \& Мулина, 2021, с. 50).

Враждебное отношение местного населения к мигрантам, как правило, способствует их консолидации, а значит, процесс складывания коммуникаций в среде поляков мог иметь более выраженный характер. Отдельный (кейсовый) анализ двух локальностей позволит оценить влияние внешних условий на формирование коммуникационных стратегий мигрантов.

\section{СООБЩЕСТВО ОКОЛИЧНОЙ ШЛЯХТЫ В ТАРЕ}

В июле 1867 г. в Таре состояло на жительстве 155 польских ссыльных, из них 38 человек были сосланы по суду с лишением прав и 117 - без ограничения прав состояния (Рощевская, 1976, с. 80). Анализ персонального состава польской ссылки выявил концентрацию в городе нескольких больших шляхетских семей, высланных из двух населенных пунктов Беличанской волости Игуменского уезда Минской губернии: Старой Володуты и Новой Володуты. По сути, это две деревни, составлявшие одну околицу Володута, расположенную в 25 верстах от Игумени (ныне Червенский район Минской области).

По данным генерал-майора Ф. И. Русинова, возле деревни Володута часто появлялись «мятежнические шайки», в трех верстах от населенного пункта было произведено нападение на начальника 29 пехотной дивизии генерала-лейтенанта Е.Е. Грунта, а в $1 \frac{1}{2}$ верстах от деревни был открыт «притон мятежников» и найдены доказательства того, что вся деревня доставляла восставшим продовольствие, а в некоторых домах стирали для них белье (Восстание в Литве и Белоруссии 1863-1864 гг., 1965, с. 440). На основании этих обвинений все «без исключения» жители Володуты были предназначены к ссылке в Сибирь (НИАБ, 1863, л. 38-39). Но сколько реально человек было выслано, исследователям не известно. Дробная шляхта из этой деревни была направлена в Минск, откуда 22 июля 1864 г. должна была быть отправлена далее по этапу, через Вильно и Петербург (Makarevich, 2014, p. 71).

В списке однодворческих и шляхетских обществ Игуменского и Новогрудского уездов, подозреваемых в поддержке повстанцев, от 31 августа 1863 г. сказано, что в Володуте было 11 дворов, где проживало 11 семей, в состав которых входил 51 человек (НИАБ, 1863, 
л. 38-39). Но относятся эти данные ко всей околице или только к одной из составлявших её деревень, нам не известно. По другим данным, к сожалению, не имеющим точной датировки, Старая Володута насчитывала 13 дворов, а Новая - 10, а значит всего в околице было 23 усадьбы. Если предположить, что в одном дворе проживала одна семья, то 2/3 населения этих двух деревень (17 семей) на 1867 г. проживали в Таре, а именно: Бобровские (2 семьи), Околовы (2 семьи), Витковские (3 семьи), Константиновичи, Цехановичи (2 семьи), Булгаки, Родкевичи (2 семьи), Крачковские, Кржечковские, Дубовик, а также вдова Антонина Борейкова и ее старший сын от первого брака Виктор Скуратович (Матвейчык, 2016, р. 25, 51, 92, 129, 206, 269, 313, 474, 529, 600; ГИАОО, 1867-1873, л. 80 об.-82, 83 об.-88, 233 об.-237; ГУТО ГАТ, $1867 \mathrm{a}$, л. 5-5 об.). В общей сложности члены этих семей насчитывали примерно 90 человек, что составляло почти 60\% всего количества польских ссыльных в Таре.

Факт концентрации в одном городе столь значительного количества ссыльных из одного населенного пункта тем более удивителен, что жителей мятежных околиц власти старались водворять в различных округах Западной Сибири, чтобы односельчане не могли контактировать друг с другом. И статейные списки подтверждают, что большая часть жителей Володуты была назначена к высылке на водворение в различные населенные пункты Томской губернии. В Тобольской губернии они, скорее всего, оказались благодаря указу исполнительной комиссии от 1865 г., разрешившему оставлять некоторых польских переселенцев в Тобольской губернии по причине расстроенного здоровья. Кроме того, шляхтичи были высланы административным порядком без лишения прав состояния. Ссылка на водворение для этой категории политических преступников заменялось ссылкой на жительство, и они переселялись в избранные правительством города, с учреждением строгого полицейского надзора. Это объясняет направление ссыльных в города Тобольской губернии. Но то, что они оказались в одном городе, не могло быть случайным стечением обстоятельств. Скорее всего, ссыльные просили направить себя именно в Тару, зная, что там уже осели их земляки.

Концентрация нескольких больших шляхетских семей придала тарской колонии польских ссыльных специфический облик. На 80 ссыльных, проживавших в городе в конце 1866 г., приходилось 85 членов семей: 14 жен и 71 ребенок (ГИАОО, 1864-1882, л. 70). Таким образом в Таре складывается редкая для сибирских городов ситуация, когда количество членов семей превосходило количество ссыльных. Для примера скажем, что, по данным официальной статистики на 1866 


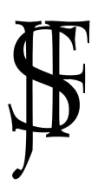

Журнал Фронтирных Исследований. 2021. No 4 | ISSN: 2500-0225

Этнические меньшинства в контактных зонах | Doi: https://doi.org/10.46539/jfs.v6i4.341

г., в городах Западной Сибири на 1762 политических преступника приходилось 345 членов их семей (107 жен и 238 детей), что составляло $19,6 \%$ от общего числа сосланных в города региона повстанцев (ГИАОО, 1864-1882, л. 70, 126, 130). Концентрация уроженцев Минской губернии, семейный статус значительной части ссыльных должны были способствовать выработке особых механизмов групповой адаптации, основанных на семейных узах и земляческих отношениях.

Ссыльные были заинтересованы в сохранении семейных связей, обеспечивавших душевный комфорт и возможность мягкой адаптации в новых условиях. Надо сказать, что семьи были большие. Кроме родителей и детей, сюда часто входили снохи, внуки, вдовые или неженатые братья и сестры. Подобная структура семьи была характерна для околичной шляхты, неохотно дробившей свои имения. Поскольку ссылка на водворение предусматривала перемещение в Сибирь всей семьи, на всех ее членов распространялись соответствующие правовые ограничения и последующие амнистии. В результате важным становится не только реальная, но и формальная (подкрепленная документами) принадлежность к семье. Например, Екатерина Кржечковская была приписана к семье свёкра, хотя после смерти 8 января 1865 г. своего супруга Альберта проживала отдельно. Когда речь зашла о переселении из Тары в одну из губерний Европейской России, вдова захотела преодолеть дорогу со своими кровными родственниками Околовыми и обратилась к властям с соответствующим прошением (ГУТО ГАТ, 1867б, л. 9-9 об.; ГУТО ГАТ, 1867-1868, л. 6-7).

Архивные документы зафиксировали бедность польской колонии в Таре. В 1865 г. тобольский губернатор А.И. Деспот-Зенович докладывал генерал-губернатору Западной Сибири А.О. Дюгамелю, что в Таре пользуется пособием 131 человек (ГИАОО, 1865-1875, л. 10), то есть более $80 \%$ от числа всех проживающих в городе польских ссыльных. Когда администрация взяла курс на уменьшение казенных выплат, ситуация в некоторых семьях стала критической. Например, Томаш Бобровский, проживая с женой и 11 детьми, получал на себя по старости 15 коп. в день и на четверых детей - по 7 1/2 коп. каждому. То есть всего семья получала от государства 45 коп. в сутки. Старший сын с женой и двумя маленькими детьми сначала получал казенное содержание, но оно вскорости было прекращено. Семья выживала за счет продажи вещей, привезенных из дома (ГУТО ГАТ, 1867а, л. 3-4). Анастасия Булгак, похоронив в 1875 г. супруга Рафаила, осталась с четырьмя детьми без средств к существованию (ГУТО ГАТ, 1874-1877, л. 5; Матвейчык, 2016, с. 92). Вдова Антонина Борейкова и её старший 
сын были лишены казенного пособия, поскольку на руках не оказалось свидетельства об их дворянском происхождении (ГУТО ГАТ, 1867a, л. 5-5 об.).

Материальные трудности и общность происхождения сплачивали ссыльных. Об этом говорит согласованность действий минской шляхты. В 1866 г., когда императорским указом было разрешено повстанцам, сосланным на жительство без лишения прав, переселиться в губернии Европейской России, ссыльные жители Володуты, все вместе, выбирают для переселения Саратовскую губернию, видимо, рассчитывая и далее сохранить свой локальный мир. Когда власти исключили Саратовскую губернию из числа местностей, определенных для переселения польских ссыльных, шляхтичи переориентировали свой выбор на Тамбовскую губернию, сохранив единодушие в выборе направления переезда. Во время посещения Тары генералгубернатором Западной Сибири бывшие жители околиц подали коллективное прошение о выдаче денег, полученных за продажу конфискованных у них имений. Прошение было принято, но через тарскую городскую полицию просителям было рекомендовано «каждому порознь об обидах своих просить» (ГУТО ГАТ, 1867-1868, л. 5).

Земляческие связи подкреплялись родственными узами. Многие жители околиц состояли между собой в родстве. Так, Екатерина Кржечковская до замужества носила фамилию Околова, а вдова Антонина Борейкова по рождению принадлежала к роду Константиновичей, а по первому браку - к роду Скуратовичей (ГУТО ГАТ, 1867б, л. 9-9об., 80-81 об.). Жители Володуты поддерживали контакты и с уроженцами соседних околиц Минской губернии. Так, на венчании Викентия Татура, уроженца околицы Сутин Игуменского уезда Минской губернии, с Анной Синкевич, уроженкой того же уезда, состоявшемся в Таре 17 января 1870 г., присутствовала значительная часть минского землячества. В метрической справке было указано, что свидетелями бракосочетания были: «Франциск Новодворский, Робер Раде, Антон Витковский и многие другие», а восприемниками родившихся у молодоженов в 1871 и 1872 гг. сыновей стали Антоний Витковский и Анастасия Булгак (ГИАОО, 1862-1882, л. 48 об.-49; НИАБ, 1870, л. 18).

Можно предположить, что возможность сохранения внутрисемейных контактов и земляческих отношений способствовала укреплению региональной идентичности, поддерживала желание вернуться на родину и ограничивала контакты с принимающим обществом. Вероятно, процесс адаптации в новом обществе в различньх семьях шел по-разному, но, когда встал вопрос о переселении в Европейскую 
Россию и возвращении на родину, ни наличие заработка, ни могилы близких не могли удержать минскую шляхту от переезда. Выехал из Тары, не пожелав отделяться от земляков, Павел Околов, похоронивший в Таре в октябре 1866 г. свою супругу Юзефу. Вернулся в родные края Томаш Бобровский, сын которого Михаил закончил тарское уездное училище, а в 1867 г. обращался с просьбой поступить на гражданскую службу (ГИАОО, 1867a, л. 1-10). По данным библиографического словаря Д.Ч. Матвейчика, практически все рассматриваемые нами семейства после получения амнистии смогли вернуться на родину.

И все же можно говорить об успешной адаптации шляхетских семей в Таре, поскольку спустя годы некоторые из них вернулись в Сибирь уже на добровольной основе. В 1890 г. в Беличанской волости Игуменского уезда 43 крестьянских хозяйства высказали желание переселиться в Сибирь. Местные власти отмечали их незавидное имущественное положение, недостаточное для переселения и обустройства в Сибири, и подчеркивали, что желание переселиться было вызвано «ложными слухами», которые распускали дворяне околицы Володуты Антон Бобровский, Петр Моравский и Виктор Скуратович (Кохнович, 2014, сс. 54-55). Скорее всего, Антон Бобровский был сыном упомянутого выше Томаша Бобровского, а Виктор Скуратович - сыном Антонины Борейковой. Видимо, пребывание в Сибири в окружении родственников и земляков не сформировало в семейной памяти образ изгнания как трагедии - что было свойственно большей части семей, разделенных ссылкой. Детские и юношеские воспоминания делали переселение в Сибирь привлекательной альтернативой бедственному проживанию в Минской губернии.

В 1893 г. в Тарском округе переселенцами Борисовского и Игуменского уездов Минской губернии был основан поселок Уразайский, впоследствии переименованный в Минск-Дворянск. Среди его жителей историки снова обнаруживают шляхетские семьи из Володуты, в том числе Петра Моравского, Виктора Скуратовича, Антона Скуратовича и Адольфа Константиновича, и вновь отмечают их стремление к сохранению земляческих связей и культурной идентичности (Токть \& Крих, 2012, с. 319).

\section{СОЛИДАРНОСТЬ ССЫЛЬНЫХ В КУРГАНЕ}

В Кургане в июле 1867 г. проживало 125 ссыльных, из которых 80 были сосланы по суду с лишением прав и 45 - без лишения прав (Рощевская, 1976, с. 80). Анализ персонального состава колонии ссыльных этого города позволяет говорить, что большинство полити- 
ческих преступников составляли молодые неженатые дворяне, высланные из различных губерний Западного края. В отличие от Тары здесь было совсем немного семейных. Жены и дети составляли лишь $16 \%$ от общего количества ссыльных (ГИАОО, 1864-1882, л. 70). Кроме того, среди поляков, сосланных в Курган, была значительная доля лиц, получивших образование. Об этом свидетельствует заявление тобольского губернатора, утверждавшего, что «людей высшего общественного положения» он по возможности старался оставлять в Тобольске или посылать в Омск и Курган (Bex, Крих \& Мулина, 2021, c. 207), а также значительное количество поляков, зарабатывавших в Кургане преподаванием и канцелярской работой в присутственных местах (Мулина, 2012).

Первые взаимные впечатления поляков и местных жителей были омрачены пожарами. По свидетельству одного из ссыльных,

«Курган в последнее время по случаю пожаров понес огромные убытки, пожар начался ночью, трудно вам объяснить о всем ужасе этаго пожара, от которого более 70 домов сгорело, и теперь даже очень трудно найти квартиру. Товарищи наши, квартиры которых сгорели, живут кое как у тех из нас, которые не подверглись той же участи» (Caban \& Mulina, 2018, p. 149).

В этих условиях ссыльные испытывали трудности с поиском квартиры и работы, а вражда между ними и сибиряками была развита настолько, что «каждый житель видел в поляке кровного врага себе, злые нелепые толки поддерживали эту вражду» (ГУТО ГАТ, 1864-1871, л. 109 об.). Не случайно в первые месяцы ссылки поляки старались держаться друг друга. В течение 1864 и 1865 гг. один из ссыльных Михаил Жаба несколько раз в своих письмах говорит о том, что поляки в Кургане живут по нескольку человек вместе и постоянно бывают одни у других (Caban \& Mulina, 2018, pp. 158, 162). Чувство отверженности и материальные трудности подтолкнули группу ссыльных к созданию товарищества взаимного пособия. История этого сообщества получила известность благодаря материалам следственного дела о создании ссыльными тайного общества и пособничестве им со стороны курганского городничего М. А. Карпинского (ГИАОО, 1867б). Некоторые материалы этого дела вместе с подборкой корреспонденции состоявших на жительстве в Кургане Михаила Жабы и Эдуарда Радванского, опубликованные в 2018 г., позволят нам детально рассмотреть сложившиеся в этом городе коммуникации ссыльных (Caban \& Mulina, 2018). 
По мнению следствия, лидерами общества были трое молодых людей, выделявшихся в курганской колонии хорошим образованием: вольнослушатель Горы-Горецкого земледельческого института дворянин Волынской губернии Иоахим Дружбацкий, дворянин Виленской губернии Михаил Жаба, окончивший медицинский факультет Московского университета со степенью лекаря, и помещик Витебской губернии Казимир Медунецкий, вышедший из Дерптского университета, не окончив курса.

Кроме того, в состав лидеров организации входили Игнатий Дубовик, Роман Зборовский, Ксаверий Сосулич и Леопольд Скродский. Все они имели дворянское происхождение и являлись выходцами из губерний Западного края. Избежавшие официальных обвинений дворянин Виленской губернии Апполинарий Косецкий и дворянин Могилевской губернии Доменик Карчевский тесно общались с перечисленными выше ссыльными и скорее всего тоже принимали участие в делах общества. Характеризуя их образовательный уровень, отметим, что Косецкий окончил уездное училище, Карчевский получил домашнее образование, а за плечами остальных, видимо, были только гимназии.

Некоторое время лидеры проживали в одной квартире в доме курганского мещанина Юрганова, где, вероятно, были опробованы совместное ведение хозяйства и складчина. Но вряд ли мы можем говорить в данном случае о создании «польского дома», слишком часто ссыльные переезжали с места на место, меняя заодно компаньонов. В частности, Михаил Жаба с момента прибытия в Курган в апреле 1864 г. до ареста в январе 1867 г. менял место проживания 6 раз. Сначала он делил квартиру с Косецким и Хоминским, которые прибыли в город примерно в то же время. Затем поселился большой компанией: c Косецким, Дружбацким, Дубовиком, Зборовским, Карчевским и Скродским в доме мещанина Юрганова. Потом некоторое время жил с Дубовиком, Сможенцким и Зборовским - в доме Важинской. Затем один - в квартире напротив больницы, потом с Константином Мошарским и курганским городовым врачом Александром Головко - в доме Тюлькина и после снова один. Сожители почти каждый раз менялись. Только Косецкий, Дубовик и Зборовский дважды меняли квартиру совместно с Михаилом, что свидетельствует об их более тесных связях. Но в целом переезды вполне соотносятся с желанием Жабы обзавестись более удобным жильем: сначала вместе с друзьями и в более дешевой квартире (за одну комнату у Юрганова Скродский платил не более 30 копеек серебра в месяц) (ГИАОО, 1867б, л. 221), потом поближе к больнице, где имел он практику; затем 
с пользой для профессионального интереса (врач Головко позволял ему пользоваться своей библиотекой) и, наконец, более удобное и комфортное одиночное проживание. Уже имея собственную квартиру, Жаба некоторое время продолжал жить с доктором Головко, объясняя, что «привык к жизни в большой колонии» (Caban \& Mulina, 2018, p. 203). Материальные мотивы были определяющими при выборе места жительства и у других ссыльных. Скродский свой переезд в многолюдную квартиру Юрганова объясняет тем, что перестали платить пособие (ГИАОО, 1867б, л. 221). Игнатий Дубовик, переехавший вместе с Жабой в менее многолюдную и, видимо, более дорогую квартиру в дом Важинской, вследствие материальных трудностей вскоре был вынужден вернуться к Юрганову. Подобных неудачных попыток улучшить условия жизни у него было пять, и всякий раз материальная сторона жизни возвращала его на старое место жительства (ГИАОО, 1867б, л. 279). Таким образом, сложно сказать, что стало определяющим в сплочении лидеров курганской организации; скорее всего, следует говорить о совокупности факторов, где, кроме практики совместного проживания и общей территории исхода (Западного края), сыграла роль близость взглядов, определяемая образованием.

Важнейшим направлением деятельности курганского общества было вспомоществование. Для решения материальных проблем была организована «подаянная кружка», куда поступали добровольные приношения каждого.

«Собранные таким образом деньги раздаваемы были нуждающимся на покупку ремесленных инструментов, независимо от сего, на оставшиеся деньги покупались гуртом жизненные припасы и после переуступались за возможно низкие цены; теми и тому подобными средствами многие получали своевременную помощь до тех пор покуда не были в возможности приискать для себя средства к существованию» (Caban \& Mulina, 2018, p. 125).

Торговля производилась без официального разрешения и существовала только несколько месяцев: с ноября-декабря 1864 г. по апрель 1865 г., а оборот почти никогда не превышал 40 рублей. Затем ссыльные организовали акционерное общество: несколько человек, объединив капитал, открыли на улице Дворянской лавочку на правах товарищества, где торговал один из поляков, на имя которого было выписано официальное разрешение (Mulina \& Legieć, 2020, p. 152). Но, видимо, и этот проект не приносил хороших доходов, потому что 
Михаил Жаба, участвовавший в работе лавочки в 1865 г., после отошел от дел, сосредоточившись на медицинской практике.

Кроме финансовых задач, общество выработало ряд этических правил, которым надлежало следовать ссыльным: «не пьянствовать, не играть в карты, особенно в азартные игры, не иметь связей с развратными женщинами, не вступать в брак» (Caban \& Mulina, 2018, p. 100). Появление моральных норм, видимо, следует связывать с высоким уровнем образования лидеров организации. Косвенно это подтверждает и проживавший в Ишиме ссыльный Цезарий Мицкевич. Он утверждал, что ходили слухи, будто бы в Кургане

«...люди побогаче и поинтеллигентнее занимаются участью беднейших и младших товарищей, печась об том, чтобы они, вследствие лишения средств материальных, и не имея сил нравственных, не падали низко в глазах общества, в среде которого жили, а тем самым могли бы выработать хорошее мнение в глазах правительства, что могло бы влиять на их будущность» (ГИАОО, 1867-1868, л. 83).

Лидеры организации видимо довольно серьезно воспринимали пропагандируемые среди соотечественников моральные нормы и не были замечены в дурных поступках. Михаил Жаба посвятил себя совершенствованию в рамках своей профессии, и, прожив значительную часть своей жизни за пределами родины, так и не женился.

Необходимость моральных ограничений была вызвана сложными взаимоотношениями польских ссыльных с местным населением. Стремление поддерживать общественный порядок в колонии означало ставку на формирование хорошего образа в глазах местного населения и администрации, что создавало благоприятную обстановку для реализации собственных жизненных стратегий. Материальное благополучие, а иногда и выживание зависело от благоприятных контактов с принимающим обществом. Это было важно и лидерам организации. Михаил Жаба занялся медицинской практикой, Карчевский состоял в услужении на заводе курганского купца 1 гильдии Шишкина; Дубовик, Скродский и Косецкий устроились в курганской городской полиции, а когда было запрещено использовать в полиции труд ссыльных, обратились к местному купечеству. Дубовик устроился в конторе купца Шишкина; Косецкий - при Федоровском винокуренном заводе, Скродский - в Земском суде.

Примечательно, что лидеры пытались максимально расширить действие общества, вовлекая в него других ссыльных, проживавших в Кургане. Однако реальное влияние курганской организации было небольшим. Группе лидеров противостояла горсть недовольных, 
вошедших в открытый конфликт с лидерами: Альберт Плисковский и Викентий Бревчинский (Caban \& Mulina, 2019, pp. 203-218) и большинство, изредка соглашавшееся на складчины, но в основном не участвующее в делах общества. К этой группе принадлежал Эдуард Радванский. На допросе он скажет, что однажды его приглашали на собрание общества, но он не пошел, и лишь единожды давал 30 коп. серебром для бедного семейства Шелни и более ничего, за что им были недовольны (Caban \& Mulina, 2018, p. 105). Эдуард сторонился активистов, однако воспользовался поддержкой других соотечественников: одолжил деньги на открытие двух питейных заведений. Его спонсоры вряд ли входили в группу Жабы, поскольку товарищество не поощряло пьянство и торговлю спиртными напитками. Но в целом мы не можем, кроме группы лидеров, определить круг лиц, участвовавших в деятельности товарищества. Видимо, с точки зрения формального членства состав организации был ограничен, но география ее воздействия на польских ссыльных была обширна. Михаил Жаба вел масштабную переписку со ссыльными, отбывавшими наказание в других населенных пунктах Сибири и Урала. Переписка позволяет говорить, что лидеры курганского товарищества пытались распространить свои идеи и создать подобные организации в Ишиме и Ялуторовске, но безуспешно. Но все же путем корреспонденции формируется разветвленная информационная сеть между ссыльными, проживавшими в различньх населенных пунктах империи, позволяющая в случае перемены места жительства получить поддержку соотечественников и оградить себя от сомнительных связей.

Товарищество взаимного пособия просуществовало недолго. В декабре 1865 г. тобольский губернатор А.И. Деспот-Зенович посетил Курган и обязал подписками всех ссыльных не участвовать в деятельности польских организаций. А в начале 1867 г. лидеры организации были арестованы и после высланы из Кургана в различные населенные пункты Сибири. Но еще до этого обозначилось несоответствие целей общества реальным потребностям большей части ссыльных. В условиях ограниченного социального статуса, отсутствия богатых соотечественников, социальный капитал сообщества оказался недостаточным для того чтобы стать центром притяжения поляков. Перспективу большинство видело в расширении контактов с принимающим обществом, где намного проще было найти работодателя, партнера по бизнесу или брачную пару. Разнородность польской ссылки препятствовала образованию больших сплоченных коллективов, и это верно не только в отношении Кургана, но и других городов. Практи- 


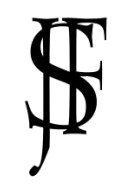

Журнал Фронтирных Исследований. 2021. No 4 | ISSN: 2500-0225

Этнические меньшинства в контактных зонах | Doi: https://doi.org/10.46539/jfs.v6i4.341

чески везде стремление поляков к единству, отчетливо ощущаемое в первые месяцы ссылки, постепенно уступало место более рациональным отношениям с окружающими, основанным на общности интересов и взаимной выгоде. В данном случае показательно замечание троицкого уездного исправника В. Фомичева:

«В 1863 году и до половины 1864 года каждые из вновь [приезжающих - ?] в г. Троицк поляков встречались прежде вселенными с особым радушием, и вообще все поляки были очень дружны между собою. Но со временем прошел энтузиазм, которым был проникнут каждый из высланных, и поляки взглянули друг на друга просто как на людей обыкновенных - увидели, что многие не только не стоят сочувствия, но не могут быть и знакомыми. Вследствие такого отрезвления взгляда друг на друга поляки разделились, и многие даже не принимаются в дома некоторых, и в настоящее время между поляками нет прежней общей дружбы, и отношения их сделались совершенно обыкновенными отношениями людей, живущих только в одном городе, но не имеющих ничего общего» (ГАОО, 1865-1866, л. 48 об.-49).

\section{ВЫВОДЫ}

Коммуникации, выстраиваемые внутри отдельных колоний польских ссыльных, определялись принадлежностью мигранта к той или иной этносоциальной группе, образованием и практической необходимостью выживания в незнакомом обществе.

В Таре самоорганизация ссыльных была облегчена наличием готовых социальных структур - больших традиционных семей и системой коммуникаций между ними, сложившейся на родине. В результате в Сибири довольно быстро формируется земляческое сообщество, подкрепленное семейно-клановыми отношениями, реальность которого доказывается наличием однотипных адаптационных стратегий и практик. Специфика имеющихся источников (делопроизводственная документация) не позволила привести примеры совместной хозяйственной деятельности или факты использования социального капитала сообщества. Но по всей видимости, такая практика существовала. Однако мы можем с уверенностью говорить о значении сообщества в психологической адаптации мигрантов. Возможность использования в Сибири привычных социальных связей снизила миграционный стресс и способствовала последующему добровольному возвращению шляхты в Сибирь.

Разнородность польской колонии в Кургане затрудняла создание сообществ. Появление товарищества взаимного пособия стало итогом усилий группы образованных дворян. На стадии формирования предполагалось, что организация станет источником финансовой, соци- 
альной и психологической поддержки для соотечественников. Но ограниченный социальный и экономический капитал сообщества сделал непривлекательным участие в нем для основной массы ссыльных. Зоной интенсивного общения оставался лишь кружок лидеров, которьх объединяли общность происхождения, схожее мировоззрение и дружеские контакты. Несмотря на то, что сеть контактов лидеров организации распространилась далеко за пределы Кургана, в самом городе существовало значительное количество ссыльных, не охваченных ее действием.

\section{Список литературы}

Caban, W. (2011). Powstanie styczniowe. Polacy i Rosjanie w XIX wieku. Wybór studiów z okazji czterdziestolecia pracy naukowej i 65. Rocznicy urodzin [The January Uprising. Poles and Russians in the XIX century. A selection of studies on the occasion of the 40th anniversary of scientific work and the 65th anniversary of birth]. Kielce: Wydawnictwo Uniwersytetu Humanistyczno-Przyrodniczego Jana Kochanowskiego. (In Polish).

Caban, W., \& Mulina, S. (2018). Syberyjska korespondencja zesłańców postyczniowych (1864-1866): "Po drodze życia wstapić przed śmiercia do Polski" [Siberian correspondence of post-civil war exiles (1864-1866): 'On the way of life to join Poland before death'.]. Kielce: Wydawnictwo Uniwersytetu Jana Kochanowskiego w Kielcach. (In Polish).

Caban, W., \& Mulina, S. (2019). Zesłańcy postyczniowi w Kurganie. Sprawa Towarzystwa Pomocy Wzajemnej [Post-civil war deportees in Kurgan. The case of the Mutual Aid Society]. Res Historica, (46), 203-218. doi: 10.17951/rh.2018.46.203-218. (In Polish)

Jędrychowska, B. (2000). Polscy zestańcy na Syberii (1830-1883). Działalność pedagogiczna, oświatowa i kulturalna [Polish exiles in Siberia (1830-1883). Pedagogical, educational and cultural activities]. Wrocław: Wydawnictwo Uniwersytetu Wrocławskiego. (In Polish).

Librowicz, Z. (1993). Polacy w Syberii [Poles in Siberia]. Wrocław. (In Polish).

Makarevich, V. (2014). Deportacje okolic szlacheckich z guberni mińskiej w latach 1863-1864 [Deportations of noblemen from Minsk province in 1863-1864]. In D. Michaluk (Ed.), Manor and Village in Lithuania and Belarus in the 19th and Early 20th Century [Manor and Village in Lithuania and Belarus in the 19th and Early 20th Century] (pp. 57-74). Warszawa: DiG. (In Polish).

Mulina, S. A., \& Legieć, J. (2020). Przedsiębiorczość jako sposób adaptacji zesłańców postyczniowych na Syberii Zachodniej [Entrepreneurship as a way of adaptation for postcivilian deportees in Western Siberia]. Przeglad Nauk Historycznych, 19(2), 141-161. doi: 10.18778/1644-857X.19.02.05. (In Polish)

Nowiński, F. (2020). Dom polski w Irkucku - życie codzienne rodziny Roszkowskich [The Polish House in Irkutsk-Everyday life of the Roszkowski family]. In E. Niebelski (Ed.), Polacy w Irkucku w XIX i XX wieku [Poles in Irkutsk in the 19th and 20th centuries] (pp. 71-98). Lublin: Towarzystwo naukowe KUL. (In Polish). 
Skok, H. (1974). Polacy nad Bajkałem 1863-1883 [Poles on Lake Baikal 1863-1883].

Warszawa: Państwowe Wydanictwo Naukowe. (In Polish).

Śliwowska, W. (1996). Polskie zesłanki na Syberii w dobie międzypowstaniowej [Polish women exiles in Siberia in the interwar period]. Miscellanea HistoricoArchivistica, 6, 175-183. (In Polish).

Śliwowska, W., \& Trynkowski, J. (2005). "Ogóły” - organizacje samopomocowe polskich zesłańców we Wschodniej Syberii w 1. 40. I 50 ["Ogóły"-Self-help organizations of Polish exiles in Eastern Siberia in the 1940s and 1950s]. In A. Brus (Ed.), Życie jest wszędzie... = Всюду жизнь...: Ruchy społeczne $w$ Polsce $i$ Rosji do II wojny światowej: Zbiór materiatów z konferencji 16-17 września $2003 r$. [Life is everywhere... = Bсюдy жизнь...: Social movements in Poland and Russia until World War II: a collection of materials from a conference September 16-17, 2003.] (pp. 147-182).

Warszawa: Wydawnictwo Neriton: Instytut Historii PAN. (In Polish).

Trynkowski, J. (2017). Polski Sybir: Zestańcy i ich życie: Narodziny mitu [Polish Siberia: The Deportees and Their Lives: The Birth of a Myth]. Warszawa: Wydawnictwo Neriton. (In Polish).

Варшавер, Е., \& Рочева, А. (2014). Сообщества мигрантов в Москве: Механизмы возникновения, функционирования и поддержания. Новое литературное обозрение, (3), 523-542.

Вех, С., Крих, А., \& Мулина, С. (2021). Участники Январского восстания, сосланные в Западную Сибирь, в восприятии российской администрации и жителей Сибири. Документы гражданской администрации, полищии и жандармского ведомства. Санкт-Петербург: Алетейя.

Восстание в Литве и Белоруссии 1863-1864 г2. (1965). Москва - Вроцлав: Наука.

Государственное учреждение Тюменской области «Государственный архив в г. Тобольске» (ГУТО ГАТ). (1864-1871). Ф. 152. On. 1. Д. 125.

Государственное учреждение Тюменской области «Государственный архив в г. Тобольске» (ГУТО ГАТ). (1865-1875). Ф. 152. On. 1. Д. 135.

Государственное учреждение Тюменской области «Государственный архив в г. Тобольске» (ГУТО ГАТ). (1867-1868). Ф. И152. Оn. 3. Д. 149.

Государственное учреждение Тюменской области «Государственный архив в г. Тобольске» (ГУТО ГАТ). (1867b). Ф. И152. Оп. 3. Д. 190.

Государственное учреждение Тюменской области «Государственный архив в г. Тобольске» (ГУТО ГАТ). (1867с). Ф. И152. On. 35. Д. 250.

Государственное учреждение Тюменской области «Государственный архив в г. Тобольске» (ГУТО ГАТ). (1874-1877). Ф. И152. Оn. 6. Д. 925.

Государственный архив Оренбургской области (ГАОО). (1865-1866). Ф. 10. Оп. 7. Д. 184.

Государственный исторический архив Омской области. (1862-1882). Ф. 348. On. 2. Д. 1.

Государственный исторический архив Омской области. (1864-1882). Ф. 3. On. 4. Д. 5769. 
Государственный исторический архив Омской области. (1865-1875). Ф. 3. On. 4. Д. 6314.

Государственный исторический архив Омской области. (1867-1868). Ф. 3. On. 5. Д. 7009.

Государственный исторический архив Омской области. (1867b). Ф. 3. Оп. 5. Д. 7581.

Государственный исторический архив Омской области. (1867-1873). Ф. 3. On. 5. Д. 7601.

Государственный исторический архив Омской области. (1867d). Ф. 3. Оп. 6. Д. 7921.

Государственный исторический архив Омской области. (1876). Ф. 3. Ор. 9. Д. 13605.

Жарова, А. С. (2014). Возникновение и развитие польской общцины в Курганском уезде Тобольской губернии во второй половине XIX - начале XX вв. (Диссертация на соискание ученой степени кандидата наук). Южно-Уральский государственный университет, Курган.

Коваль, С. Ф. (1965). Революционная деятельность польских политических ссыльных в Сибири в 60-е гг. XIX в. В Сибирь периода капитализма. Вып. 2. Экономическое и общественно-политическое развитие Сибири в 1861-1917 г2. (с. 123-132). Новосибирск: Наука.

Кохнович, В. А. (2014). Особенности хозяйства и социального состава переселенцев из Минской губернии конца XIX в. В А. П. Сальков \& О. А. Яновский (Ред.), Российские и славянские исследования: Науч. Сб. Вып. 9. (с. 50-60). Минск: БГУ.

Матвейчык, Д. Ч. (2016). Удзельнікі паўстання 1863-1864 гадоў: Біяграбічны слоўнік (паводле матэрыялаў Наџыянальнага гістарычнага архіва Беларусі) [Participants of the uprising of 1863-1864: biographical dictionary (according to the materials of the National Historical Archive of Belarus)]. Мінск: Беларусь. (In Belarusian).

Мулина, С. А. (2012). Мигранты поневоле: Адаптация ссыльных участников Польского восстания 1863 года в Западной Сибири. Санкт-Петербург: Алетейя.

Нам, И. (2010). Исторические особенности формирования и деятельности диаспорных институтов в Сибири (XIX - начало XX в.). В В. Дятлов (Ред.), Миграции и диаспоры в сочиокультурном, политическом и экономическом пространстве Сибири. Рубежи XIX-XX и XX-XXI веков (с. 315-356). Иркутск: Оттиск.

Национальный исторический архив Беларуси (НИАБ). (1863). Ф. 295. Оп. 1. Д. 1522.

Национальный исторический архив Беларуси (НИАБ). (1870). Ф. 1781. On. 36. Д. 433.

Оплаканская, Р. В. (2004). Землячества поляков в Сибири как фактор сохранения национальной идентичности в условиях иной этнокультурной среды (первая половина ХІХ в.). В Д. В. Резун (Ред.), Сибирский плавильный котел: Социально-демографические процессы в Северной Азии XVI - начала XX века (с. 47-51). Новосибирск: Сибирский Хронограф.

Островский, Л. К. (2019). Деятельность польских общественных организаций в Сибири в 1917-1920 гг. Исторический курьер, (5), 164-175. doi: 10.31518/26189100-2019-5-13 
Рощевская, Л. П. (1976). История политической ссылки в Западной Сибири во второй половине XIX в. (60 - нач. 80-х годов). Тюмень: Тюменский государственный университет.

Токть, С. М., \& Крих, А. А. (2012). Минская шляхта в Беларуси и Сибири. Вестник Омского университета, (2), 315-321.

Цабан, В. (2021). Виды «семейных домов» польских политических ссыльных в 40-70-х гг. ХІХ в. В И. В. Нам (Ред.), ХIV Конгресс антропологов и этнологов России: Сборник материалов. Москва; Томск: Издательство Томского государственного университета.

\section{References}

Caban, W. (2011). Powstanie styczniowe. Polacy i Rosjanie w XIX wieku. Wybór studiów $z$ okazji czterdziestolecia pracy naukowej i 65. Rocznicy urodzin [The fanuary Uprising. Poles and Russians in the XIX century. A selection of studies on the occasion of the 40th anniversary of scientific work and the 65th anniversary of birth]. Kielce: Wydawnictwo Uniwersytetu Humanistyczno-Przyrodniczego Jana Kochanowskiego. (In Polish).

Caban, W., \& Mulina, S. (2018). Syberyjska korespondencja zestańców postyczniowych (18641866): "Po drodze życia wstapić przed śmiercia do Polski" [Siberian correspondence of post-civil war exiles (1864-1866): 'On the way of life to join Poland before death'.]. Kielce: Wydawnictwo Uniwersytetu Jana Kochanowskiego w Kielcach. (In Polish).

Caban, W., \& Mulina, S. (2019). Zesłańcy postyczniowi w Kurganie. Sprawa Towarzystwa Pomocy Wzajemnej [Post-civil war deportees in Kurgan. The case of the Mutual Aid Society]. Res Historica, (46), 203-218. doi: 10.17951/rh.2018.46.203-218. (In Polish)

Jędrychowska, B. (2000). Polscy zestańcy na Syberii (1830-1883). Działalność pedagogiczna, oświatowa i kulturalna [Polish exiles in Siberia (1830-1883). Pedagogical, educational and cultural activities]. Wrocław: Wydawnictwo Uniwersytetu Wrocławskiego. (In Polish).

Kokhnovich, V. A. (2014). Peculiarities of the Economy and Social Composition of Migrants from Minsk Province in the Late 19th Century. B A. P. Sal'kov \& O. A. Yanovsky (Eds.), Russian and Slavic Studies: Scientific Collection, Issue 9. (pp. 50-60). Minsk: BSU. (In Russian).

Kowal, S. F. (1965). Revolutionary Activity of Polish Political Exiles in Siberia in the 1960s. In Siberia in the Period of Capitalism. Vol. 2. Economic and Socio-Political Development of Siberia in 1861-1917. (pp. 123-132). Novosibirsk: Nauka. (In Russian).

Librowicz, Z. (1993). Polacy w Syberii [Poles in Siberia]. Wrocław. (In Polish).

Makarevich, V. (2014). Deportacje okolic szlacheckich z guberni mińskiej w latach 18631864 [Deportations of noblemen from Minsk province in 1863-1864]. In D. Michaluk (Ed.), Manor and Village in Lithuania and Belarus in the 19th and Early 20th Century [Manor and Village in Lithuania and Belarus in the 19th and Early 20th Century] (pp. 57-74). Warszawa: DiG. (In Polish).

Matveychyk, D. Ch. (2016). Participants of the uprising of 1863-1864: biographical dictionary (according to the materials of the National Historical Archive of Belarus).

Minsk: Belarus. (In Belarusian). 
Mulina, S. A. (2012). Migrants by Force: The Adaptation of the Exiled Participants of the Polish Uprising of 1863 in Western Siberia. Saint Petersburg: Aletheia. (In Russian).

Mulina, S. A., \& Legieć, J. (2020). Przedsiębiorczość jako sposób adaptacji zesłańców postyczniowych na Syberii Zachodniej [Entrepreneurship as a way of adaptation for postcivilian deportees in Western Siberia]. Przegląd Nauk Historycznych, 19(2), 141-161. doi: 10.18778/1644-857X.19.02.05. (In Polish)

Nam, I. (2010). Historical Peculiarities of the Formation and Activity of Diaspora Institutions in Siberia (XIX - beginning of XX century). In V. Dyatlov (Ed.), Migrations and Diasporas in the Sociocultural, Political, and Economic Space of Siberia. The Turns of the $X I X-X X$ and $X X-X X I$ Centuries. (pp. 315-356). Irkutsk: Imprint. (In Russian).

National Historical Archives of Belarus. (1863). F. 295. In. 1. C. 1522.

National Historical Archives of Belarus. (1870). F. 1781. In. 36. C. 433. (In Russian).

Nowiński, F. (2020). Dom polski w Irkucku - życie codzienne rodziny Roszkowskich [The Polish House in Irkutsk-Everyday life of the Roszkowski family]. In E. Niebelski (Ed.), Polacy w Irkucku w XIX i XX wieku [Poles in Irkutsk in the 19th and 20th centuries] (pp. 71-98). Lublin: Towarzystwo naukowe KUL. (In Polish).

Oplakanskaya, R. V. (2004). The Poles in Siberia as a Factor in the Preservation of National Identity in a Different Ethno-Cultural Environment (First Half of the 19th Century). In D. V. Rezun (Ed.), The Siberian Melting Pot: Social and Demographic Processes in 16th - Early 20th Century North Asia (pp. 47-51). Novosibirsk: Siberian Chronograph. (In Russian).

Ostrowski, L. K. (2019). The Activity of Polish Public Organizations in Siberia in 1917-1920. Historical Courier, (5), 164-175. doi: 10.31518/2618-9100-2019-5-13 (In Russian).

Roschevskaya, L. P. (1976). History of Political Exile in Western Siberia in the Second Half of the 19th Century. (60s - early 80s). Tyumen: Tyumen State University. (In Russian).

Skok, H. (1974). Polacy nad Bajkatem 1863-1883 [Poles on Lake Baikal 1863-1883]. Warszawa: Państwowe Wydanictwo Naukowe. (In Polish).

Śliwowska, W. (1996). Polskie zesłanki na Syberii w dobie międzypowstaniowej [Polish women exiles in Siberia in the interwar period]. Miscellanea HistoricoArchivistica, 6, 175-183. (In Polish).

Śliwowska, W., \& Trynkowski, J. (2005). “Ogóły” - organizacje samopomocowe polskich zesłańców we Wschodniej Syberii w 1. 40. I 50 ["Ogóły"-Self-help organizations of Polish exiles in Eastern Siberia in the 1940s and 1950s]. In A. Brus (Ed.), Życie jest wszędzie... = Всюду жизнь...: Ruchy społeczne $w$ Polsce $i$ Rosji do II wojny światowej: Zbiór materiatów $z$ konferencji 16-17 września $2003 r$. [Life is everywhere... = Bсюдy жизнь...: Social movements in Poland and Russia until World War II: a collection of materials from a conference September 16-17, 2003.] (pp. 147-182).

Warszawa: Wydawnictwo Neriton: Instytut Historii PAN. (In Polish).

State Archive of the Orenburg Region. (1865-1866). F. 10. In. 7. C. 184. (In Russian).

State Historical Archive of the Omsk Region. (1862-1882). Ф. 348. Оп. 2. Д. 1. (In Russian).

State Historical Archive of the Omsk Region. (1864-1882). F. 3. In. 4. C. 5769. (In Russian). 


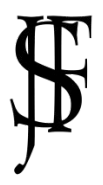

Журнал Фронтирных Исследований. 2021. No 4 | ISSN: 2500-0225

Этнические меньшинства в контактных зонах | Doi: https://doi.org/10.46539/jfs.v6i4.341

State Historical Archive of the Omsk Region. (1865-1875). F. 3. In. 4. C. 6314. (In Russian).

State Historical Archive of the Omsk Region. (1867-1868). F. 3. In. 5. C. 7009. (In Russian).

State Historical Archive of the Omsk Region. (1867-1873). F. 3. In. 5. C. 7601. (In Russian).

State Historical Archive of the Omsk Region. (1867b). F. 3. In. 5. C. 7581. (In Russian).

State Historical Archive of the Omsk Region. (1867d). F. 3. In. 6. C. 7921. (In Russian).

State Historical Archive of the Omsk Region. (1876). F. 3. In. 9. C. 13605. (In Russian).

State Institution of the Tyumen Region "Tobolsk State Archives”. (1864-1871). F. 152. In. 1. C. 125. (In Russian).

State Institution of the Tyumen Region "Tobolsk State Archives". (1865-1875). F. 152. In. 1. C. 135. (In Russian).

State Institution of the Tyumen Region "Tobolsk State Archives". (1867-1868). F. И152. In. 3. C. 149. (In Russian).

State Institution of the Tyumen Region “Tobolsk State Archives”. (1867b). F. I152. In. 3. C. 190. (In Russian).

State Institution of the Tyumen Region "Tobolsk State Archives". (1867c). F. I152. In. 35. C. 250. (In Russian).

State Institution of the Tyumen Region "Tobolsk State Archives”. (1874-1877). F. I152. In. 6. C. 925. (In Russian).

Tokt, S. M., \& Krich, A. A. (2012). The Minsk nobility in Belarus and Siberia. Bulletin of Omsk University, (2), 315-321. (In Russian).

Trynkowski, J. (2017). Polski Sybir: Zestańcy i ich życie: Narodziny mitu [Polish Siberia: The Deportees and Their Lives: The Birth of a Myth]. Warszawa: Wydawnictwo Neriton. (In Polish).

Tsaban, V. (2021). Types of "family homes" of Polish political exiles in the 1940s-70s. In I. V. Nam (Ed.), The 14th Congress of Anthropologists and Ethnologists of Russia: Proceedings. Moscow; Tomsk: Tomsk State University Press. (In Russian).

Uprising in Lithuania and Belorussia 1863-1864. (1965). Moscow - Wroclaw: Nauka. (In Russian).

Varshaver, E., \& Rocheva, A. (2014). Migrant Communities in Moscow: Mechanisms of Emergence, Functioning and Maintenance. New Literary Review, (3), 523-542. (In Russian).

Veh, S., Krich, A., \& Mulina, S. (2021). Participants of the fanuary Uprising exiled to Western Siberia in the perception of the Russian administration and residents of Siberia. Documents of the Civil Administration, Police, and Gendarme Department. St. Petersburg: Aletheia. (In Russian).

Zharova, A. S. (2014). The Emergence and Development of the Polish Community in Kurgan Uyezd, Tobolsk Province in the Second Half of the 19th - Early 20th Centuries. (Ph. D. thesis). The Southern Urals State University, Kurgan. (In Russian). 